\title{
Various forms of mouse lactoferrins: purification and characterization
}

\author{
Sheng-Hsiang Li, Yee-Hsiung Chen* \\ Institute of Biochemical Sciences, College of Science, National Taiwan University and Institute of Biological Chemistry, \\ Academic Sinica, P.O. Box 23-106, Taipei, Taiwan
}

Received 22 June 1998; received in revised form 21 December 1998; accepted 20 January 1999

\begin{abstract}
This work was conducted to study the microheterogeneity of mouse lactoferrin (LF). Two forms, $\mathrm{LF}_{1}$ and $\mathrm{LF}_{2}$, could be purified from uterine luminal fluid by ion-exchange HPLC on a Protein PAK SP 5PW column. Another form, $\mathrm{LF}_{3}$, was purified from the epididymis homogenate by affinity chromatography on a column of Protein A-Sepharose coupled with the purified $\mathrm{LF}_{2}$ antibody that was prepared to give no crossreaction with serum albumin. Both $\mathrm{LF}_{1}$ and $\mathrm{LF}_{2}$ showed a $M_{\mathrm{r}}$ 74000 band while $\mathrm{LF}_{3}$ gave a $M_{\mathrm{r}} 70000$ band on reducing SDS-PAGE. All of them were reduced to a $M_{\mathrm{r}} 68000$ band after they had been digested with $N$-glycosidase F. The data from automated Edman degradation confirmed the completely identical 19 amino acid sequences in the N-terminal regions of these three LFs, except the lack of N-terminal Lys-Ala of $\mathrm{LF}_{2} / \mathrm{LF}_{3}$ in $\mathrm{LF}_{1}$. LF in tissue homogenates was immunodetected by Western blot procedure using the purified $\mathrm{LF}_{2}$ antibody. Different amounts of LF with a molecular mass of the 70000 or 74000 were distributed in the non-sexual organs such as kidney, spleen, lung, heart and liver and the sexual glands including epididymis, vagina, uterus, ovary and prostate. No LF was detected in stomach, intestine, testis and seminal vesicle. (c) 1999 Elsevier Science B.V. All rights reserved.
\end{abstract}

Keywords: Lactoferrins

\section{Introduction}

Lactoferrin (LF) is present mainly in milk [1], other external secretions [2] and the secondary granules of neutrophils [3]. It has been associated with iron adsorption in newborn infants [4], bactericidal activity [5,6], antiviral activity [7], growthstimulatory activity [8], and immune modulation (for reviews, see Refs. $[9,10])$. The recent study of $\mathrm{He}$

*Corresponding author. Fax: +886-2-2363-5038.

E-mail address: bc304@gate.sinica.edu.tw (Y. Chen) and Furmanski suggests it to be a potential transcription activator [11].

LF has been described in the human reproductive tract during the menstrual cycle [12] and in human seminal plasma as one of the major sperm-coating antigens $[13,14]$. However, its role in reproductive biology has not received attention until it was identified to be a major protein secreted from the uterine epithelial cells of both adult and immature female mice after estrogen treatment $[15,16]$. Detailed analyses of LF and its RNA message during the natural estrus cycle $[17,18]$ and the preimplantation period [19] reveal the regulation of its expression by ovarian steroids. LF is present in the 
epididymis of mouse and porcine [20,21]. Its expression in the prepubertal epididymis can be stimulated by estrogen [20].

LF is glycosylated. The heterogeneity due to different glycosylation occurs in porcine and human LF [22,23]. Various forms of mouse LF have been suspected also $[16,17]$. This work was conducted to clarify the microheterogeneity of LF in the mouse reproductive tracts. We purified and identified two forms of $M_{\mathrm{r}} 74000 \mathrm{LF}$ in uterine luminal fluid, and one form of $M_{\mathrm{r}} 70000 \mathrm{LF}$ in epididymis homogenate. Moreover, our results confirmed no LF other than $M_{\mathrm{r}} 70000$ or 74000 in the sexual and nonsexual organs.

\section{Experimental}

\subsection{Materials}

Sephadex G-100, protein molecular mass markers and Protein A-Sepharose CL-4B were purchased from Pharmacia (Uppsala, Sweden). CM-Affi-Gel Blue and Econo columns were obtained from BioRad Labs. (Richmond, CA, USA). A Protein PAK SP 5PW column was obtained from Waters (Milford, MA, USA). $N$-Glycosidase F, protease inhibitor cocktail tablets and phenylmethylsulfonyl fluoride (PMSF) were products of Boehringer-Mannheim (Mannheim, Germany). Aminolink gel, BCA protein assay kit and enhanced chemiluminescent substrate were obtained from Pierce (Rockford, IL, USA). Mouse serum albumin, horseradish peroxidaseconjugated goat anti-rabbit antibody and diethylstilbestrol (DES) were from Sigma (St. Louis, MO, USA). All chemicals were reagent grade.

\subsection{Animals}

ICR mice (Charles River Labs., Wilmington, MA, USA) were maintained and bred in the animal center at the College of Medicine, National Taiwan University. Animals were treated following the institutional guidelines for the care and use of experimental animals. The mature males (6-8 weeks old), mature females (6-8 weeks old) and immature females (21 days old) were used throughout the study. Animals were sacrificed by cervical dislocation. DES in corn oil with a daily dosage of $100 \mathrm{ng} / \mathrm{g}$ of body mass was injected subcutaneously to immature females for three consecutive days. We collected uterine luminal fluid (ULF) of either the DES-treated animals on day 24 of age or the mature females in the proestrus stage, which was verified by the vaginal test. Twenty $\mu l$ of $500 \mathrm{~m} M$ EDTA and $100 \mu \mathrm{l}$ of $100 \mathrm{~m} M$ PMSF in isopropanol were added to $10 \mathrm{ml}$ of ULF and the preparation was stored at $-70^{\circ} \mathrm{C}$ before use.

\subsection{Purification of LF from mouse ULF}

LF was partially purified from ULF by a modified method [16]. Briefly, the ULF preparation was directly subjected to gel filtration on a Sephadex G-100 column $(80 \times 2.6 \mathrm{~cm})$, and the LF fraction was rechromatographied on a CM-Affi-Gel Blue column $(10 \times 1.5 \mathrm{~cm})$. About $500 \mu \mathrm{g}$ of the partially purified protein sample in $200 \mu \mathrm{l}$ of $20 \mathrm{mM}$ phosphate buffer at $\mathrm{pH} 7.4$ or $150 \mu \mathrm{l}$ of the ULF preparation from the mature females or DES-treated immature females was further resolved by high-performance liquid chromatography (HPLC) on a Protein PAK SP 5PW column $(7.5 \mathrm{~cm} \times 7.5 \mathrm{~mm})$ preequilibrated with the same buffer. The column was washed with a linear gradient of $0-0.6 \mathrm{M}$ sodium acetate in the buffer at room temperature. Fractions $(500 \mu \mathrm{l})$ were collected and were monitored by the optical density at $280 \mathrm{~nm}$. The chromatography was performed with a Waters $650 \mathrm{E}$ advanced protein purification system attached to a Waters 486 tunable absorbance detector.

\subsection{Purification of $L F_{2}$ antibody and $L F_{3}$}

According to the procedures recommended by the commercial source, Aminolink gel covalently linked with mouse serum albumin or $\mathrm{LF}_{2}$ was prepared. Around $1.0 \mathrm{mg}$ of mouse serum albumin or $0.5 \mathrm{mg}$ of $\mathrm{LF}_{2}$ was coupled to $1.0 \mathrm{ml}$ of the affinity gel.

Antiserum against $\mathrm{LF}_{2}$ was raised in New Zealand White rabbits. $\mathrm{LF}_{2}$ in normal saline $(2 \mathrm{mg} / \mathrm{ml})$ was mixed with Freund's complete adjuvant $(1: 2, \mathrm{v} / \mathrm{v})$. Rabbit received intrasplenic injection of $300 \mu l$ of the mixture. The antiserum was collected eight weeks later. Around $1.5 \mathrm{ml}$ of the antiserum was applied to a column $(2.5 \times 1.0 \mathrm{~cm})$ of Aminolink gel coupled with mouse serum albumin. The column was washed with phosphate-buffered saline (PBS) (1.5 
$\mathrm{m} M \mathrm{KH}_{2} \mathrm{PO}_{4}, 8.1 \mathrm{~m} M \mathrm{Na}_{2} \mathrm{HPO}_{4}, 137 \mathrm{~m} M \mathrm{NaCl}$, $2.7 \mathrm{mM} \mathrm{KCl}, \mathrm{pH} \mathrm{7.4)}$ and the non-retarded portion was further subjected to affinity chromatography on a column $(2.5 \times 1.0 \mathrm{~cm})$ of Aminolink gel linked with $\mathrm{LF}_{2}$ preequilibrated with $\mathrm{PBS}$ at $4^{\circ} \mathrm{C}$. The column was washed with PBS to remove the non-retarded portion and antibody to $\mathrm{LF}_{2}$ was then eluted from the column with $0.1 \mathrm{M}$ glycine ( $\mathrm{pH}$ 3.0) at a flow-rate of $18 \mathrm{ml} / \mathrm{h}$ that was controlled by a peristaltic pump. The eluent was neutralized with 0.1 volume of $1.0 \mathrm{M}$ Tris $-\mathrm{HCl}$ at $\mathrm{pH} 8.2$, dialyzed against deionized water at $4^{\circ} \mathrm{C}$ and lyophilized. About $0.8 \mathrm{mg}$ of the $\mathrm{LF}_{2}$ antibody could be prepared from $1.5 \mathrm{ml}$ of antiserum. The lyophilized sample was redissolved in PBS containing $10 \%$ glycerol and $0.05 \% \mathrm{NaN}_{3}$ at a final concentration of $10 \mathrm{mg} / \mathrm{ml}$ and stored at $-20^{\circ} \mathrm{C}$. The specificity of the antibody was verified by assessment of its immunoaffinity to purified $\mathrm{LF}_{2}$ and mouse serum albumin using the Western blot procedure.

The affinity gel of the $\mathrm{LF}_{2}$ antibody-Protein ASepharose was prepared by following the method of Schneider et al. [26]. Around $3 \mathrm{mg}$ of the antibody was coupled to $1.5 \mathrm{ml}$ of Protein A-Sepharose CL4B. The affinity gel was packed into a small Econo column $(1.5 \times 1.0 \mathrm{~cm})$. Around $20 \mathrm{mg}$ of protein in the soluble portion of mouse epididymal homogenates was applied to the column preequilibrated with PBS at $4^{\circ} \mathrm{C}$. The column was washed to remove the non-retarded portion with the same buffer and $\mathrm{LF}_{3}$ was washed out from the column with $0.1 \mathrm{M}$ glycine $(\mathrm{pH} \mathrm{3.0)}$ at a flow-rate of $12 \mathrm{ml} / \mathrm{h}$. Recovery of the protein sample was followed the procedures mentioned above.

\subsection{Protein analysis and Western blot procedure}

The amino acid sequences of a protein were determined by automated Edman degradation with a gas-phase sequenator (Applied Biosystems, Foster City, CA, USA).

Removal of the $\mathrm{N}$-glycoconjugate from a glycoprotein was followed the method of Tarentino and Plummer Jr. [24]. Protein was boiled in $1.0 \%$ sodium dodecyl sulfate (SDS) and incubated with $N$-glycosidase F (40 U/mg of protein) in $20 \mathrm{mM}$ sodium phosphate at $\mathrm{pH} 7.2$ in the presence of 50 $\mathrm{m} M$ EDTA, $0.5 \%$ Nonidet $\mathrm{P}-40$, and $10 \mathrm{~m} M$ sodium azide for $16 \mathrm{~h}$ at $37^{\circ} \mathrm{C}$.

Around $5.0 \mathrm{~g}$ of tissue from both the mature male mice and the mature female mice was homogenized in $1.5 \mathrm{ml}$ of PBS containing the protease inhibitor cocktail and $1.0 \mathrm{~m} M$ PMSF. The homogenates were centrifuged at $120000 \mathrm{~g}$ for $30 \mathrm{~min}$. The protein concentration in the supernatant was determined with a BCA protein assay kit. The supernatant containing $100 \mu \mathrm{g}$ of the protein extract was mixed with equal volume of the sample buffer $(0.125 \mathrm{M}$ Tris- $\mathrm{HCl}$, $4.0 \%$ SDS, $20 \%$ glycerol, $10 \%$ 2-mercaptoethanol, $\mathrm{pH}$ 6.8) and heated at $100^{\circ} \mathrm{C}$ for 3 min prior to SDS-polyacrylamide gel electrophoresis (PAGE) which was performed on an $8.0 \%$ gel slab $(8.2 \times$ $7.3 \times 0.075 \mathrm{~cm})$ according to the method of Laemmli [25]. The protein components were transferred from the gel to a polyvinylidene difluoride (PVDF) membrane by a diffusion method. Briefly, the SDSPAGE gel was sandwiched by two pieces of PVDF membrane and immersed in PBS containing $1.0 \mathrm{mM}$ EDTA in a TE22 transphor tank (Hoefer, Mighty Small Transphor Tank). The solution was gently stirred at $4^{\circ} \mathrm{C}$ for $60 \mathrm{~h}$. Proteins were almost completely transferred to the membranes as checked by staining the gel with $0.1 \%$ Coomassie Brilliant Blue. The membrane was blocked in PBS containing $0.1 \%$ Tween 20 and $5.0 \%$ skim milk. LF was immunodetected by Western blot procedure, using the purified $\mathrm{LF}_{2}$ antibody $(0.4 \mu \mathrm{g} / \mathrm{ml})$ and horseradish peroxidase-conjugated goat anti-rabbit antibody diluted to $1: 8000$ in the blocking solution. Finally, enhanced chemiluminescent substrate was employed to visualize the signal.

\section{Results}

\subsection{Purification of $L F$ and its antibody}

Previously, one $M_{\mathrm{r}} 74000 \mathrm{LF}$ in ULF of CD-1 mice was purified by a series of isolation procedures including chromatography and rechromatography on a Sephadex G-100 column and affinity chromatography on a CM-Affi-Gel blue column [16]. The last step was attempted to remove the contaminant of serum albumin. We followed these procedures to isolate LF from ULF of the DES-stimulated imma- 
ture ICR mice. However, the protein sample could be further resolved by ion-exchange HPLC on a SP column to four components, two minor ones denoted I and II and two major ones denoted III and IV in Fig. 1A. We applied the HPLC method to resolve directly the components of ULF. Two peaks corresponding to III and IV of Fig. 1A appeared in the chromatograms of ULF freshly collected from the DES-stimulated immature mice or the adult mice in the proestrus stage (Fig. 1B and C). However, peak $\mathrm{IV}$ in Fig. $1 \mathrm{~B}$ and $\mathrm{C}$ was heterogeneous as evidenced

(A)

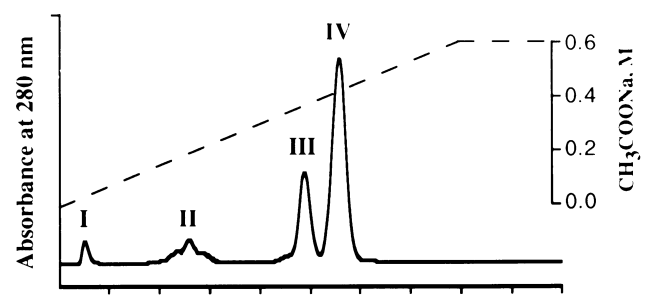

(B)

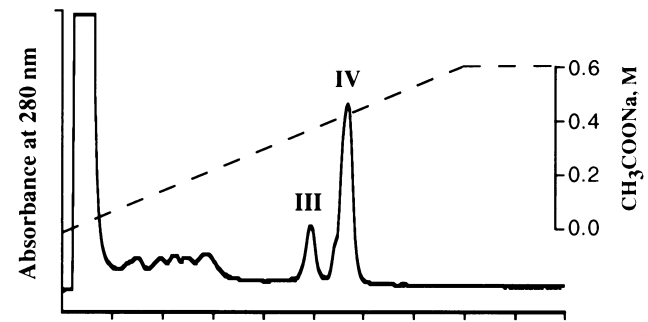

(C)

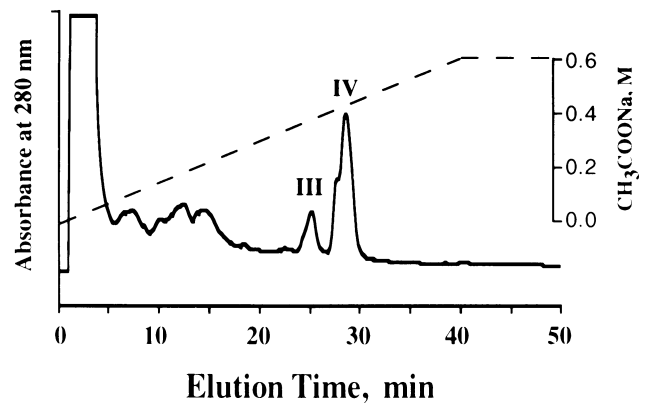

Fig. 1. Purification of LF in the mouse ULF. The protein samples were subjected to HPLC on a Waters Protein Pak SP 5PW column preequilibrated with $20 \mathrm{mM}$ phosphate buffer at $\mathrm{pH}$ 7.4. A linear gradient of 0-0.6 $M$ sodium acetate indicated by a dashed line was applied to the column at a flow-rate of $1 \mathrm{ml} / \mathrm{min}$ for $40 \mathrm{~min}$. (A) The LF sample partially purified from ULF of the DESstimulated immature mice through CM-Affi-Gel Blue affinity chromatography according to the previous method [16]. (B) ULF collected from the DES-treated immature mice. (C) ULF collected from mature mice in proestrus stage. by the appearance of a shoulder in the front side of the peak.

Both peaks III and peak IV of Fig. 1A gave only one $M_{\mathrm{r}} 74000$ band on reducing SDS-PAGE gel (lanes 1 and 2 of Fig. 2). The $M_{\mathrm{r}} 74000$ protein was not found in peaks I and II of Fig. 1A. Apparently, peaks III and IV are two forms of lactoferrin. Tentatively, we designated peaks III and IV of Fig. $1 \mathrm{~A}$ to be $\mathrm{LF}_{1}$ and $\mathrm{LF}_{2}$, respectively. Only one $M_{\mathrm{r}}$ 74000 band and trace of minor components other than $\mathrm{LF}_{1} / \mathrm{LF}_{2}$ appeared on the electrophoretic patterns of peak III in either Fig. 1B or C (lanes 3 and 5 of Fig. 2). The same situation happened in both peak IV and its shoulder in either Fig. 1B and C (lanes 4, 6 and 7 of Fig. 2). These data supported the presence of both $\mathrm{LF}_{1}$ and $\mathrm{LF}_{2}$ in ULF and suggested an heterogeneous population of different $\mathrm{LF}_{2}$ form.

In spite of our efforts to purify $\mathrm{LF}_{1} / \mathrm{LF}_{2}$, trace amounts of serum albumin remained in the protein sample. As a result, the antiserum collected from rabbits immunized with $\mathrm{LF}_{2}$ retained weak immunoaffinity to mouse serum albumin in addition to its strong immunoaffinity to $\mathrm{LF}_{1} / \mathrm{LF}_{2}$. To eliminate the immunoactivity due to serum albumin, we passed the antiserum through an affinity column of Aminolink gel coupled with mouse serum albumin. The $\mathrm{LF}_{2}$ antibody was further purified by affinity chromatography on a column of Aminolink gel coupled with $\mathrm{LF}_{2}$. As shown in Fig. 3, we could detect LF to a

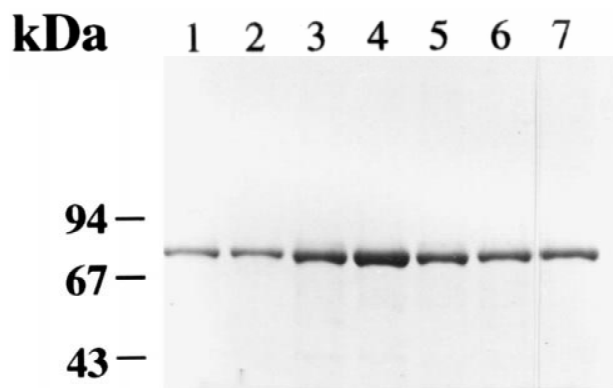

Fig. 2. Determination of the homogeneity of LFs by SDS-PAGE. The protein samples were resolved by reducing SDS-PAGE on an $8.0 \%$ gel slab $(8.2 \times 7.3 \times 0.075 \mathrm{~cm})$ : lane 1, peak III of Fig. $1 \mathrm{~A}(1$ $\mu \mathrm{g})$; lane 2, peak IV of Fig. 1A $(1 \mu \mathrm{g})$; lane 3, peak III of Fig. 1B $(2.5 \mu \mathrm{g})$; lane 4, peak IV of Fig. 1B $(2.5 \mu \mathrm{g})$; lane 5, peak III of Fig. 1C $(2 \mu \mathrm{g})$; lane 6 , peak IV of Fig. 1C $(2 \mu \mathrm{g})$; lane 7 , the shoulder of peak IV of Fig. 1C $(2 \mu \mathrm{g})$. The gel was stained with $0.1 \%$ Coomassie Brilliant Blue to reveal the protein bands. 
(A)

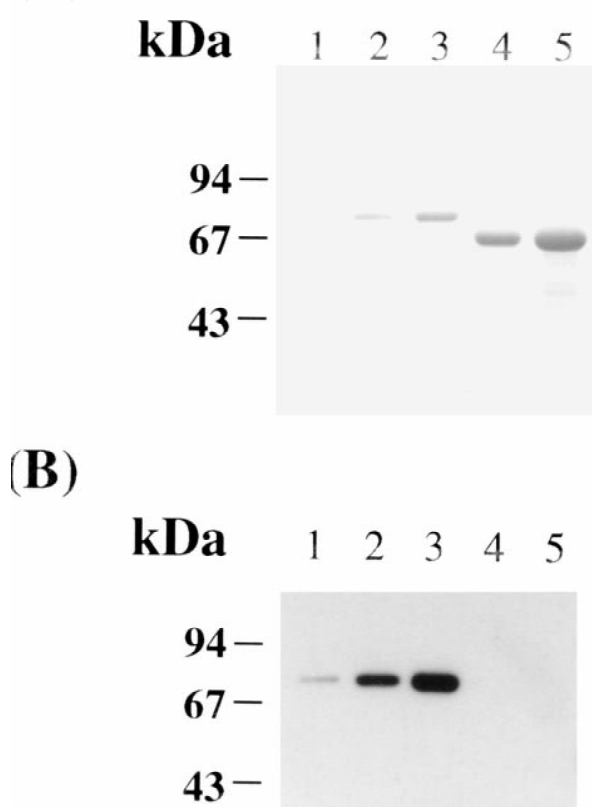

Fig. 3. Specificity of the purified $\mathrm{LF}_{2}$ antibody. The proteins were resolved by SDS-PAGE on an $8.0 \%$ polyacrylamide gel slab $(8.2 \times 7.3 \times 0.075 \mathrm{~cm})$. (A) The proteins were stained with Coomassie Brilliant Blue dye; lanes 1-3, $50 \mathrm{ng}, 200 \mathrm{ng}$ and 500 $\mathrm{ng}$ of $\mathrm{LF}_{2}$; lanes 4 and 5, 2 and $5 \mu \mathrm{g}$ of mouse serum albumin. (B) The proteins in the gel (A) were transferred to a PVDF membrane by a diffusion method and immunodetected by Western blot with the purified $\mathrm{LF}_{2}$ antibody in the blocking solution (0.4 $\mu \mathrm{g} / \mathrm{ml}$ ) (see Sections 2.4 and 2.5 for details).

low limit of $50 \mathrm{ng}$ by Western blot procedure, using the purified $\mathrm{LF}_{2}$ antibody which showed no immunoactivity to mouse serum albumin even when $5 \mu \mathrm{g}$ of the protein was tested.

LF is present in epididymis [20,21]. We purified the protein from the soluble fraction of epididymis homogenates by affinity chromatography on a column of Protein A-Sepharose coupled with the purified $\mathrm{LF}_{2}$ antibody. The protein was tentatively designated as $\mathrm{LF}_{3}$ (see Experimental).

\subsection{Characterization of $L F$}

We characterized $\mathrm{LF}_{1}$ and $\mathrm{LF}_{2}$ of Fig. $1 \mathrm{~A}$ and $\mathrm{LF}_{3}$ by comparing their molecular sizes and $\mathrm{N}$-terminal sequences. $\mathrm{LF}_{3}$ is smaller than $\mathrm{LF}_{1} / \mathrm{LF}_{2}$. It gave a $M_{\mathrm{r}} 70000$ band on reducing SDS-PAGE gel (cf. lane 5 of Fig. 4A). Digestion of $\mathrm{LF}_{1}, \mathrm{LF}_{2}$ or $\mathrm{LF}_{3}$ with $\mathrm{N}$-glycosidase $\mathrm{F}$ reduced their molecular mass to a similar one about $M_{\mathrm{r}} 68000$ (cf. lanes 2, 4 and 6 of Fig. 4A). Automated Edman degradation of $\mathrm{LF}_{1}$, $\mathrm{LF}_{2}$ or $\mathrm{LF}_{3}$ up to 19 cycles gave reliable data for their N-terminal sequences, which can be completely aligned with the protein sequences of LF deduced from the cDNA of CD-1 mice [15] (Fig. 4B). The $\mathrm{N}$-terminal sequences of $\mathrm{LF}_{1}$ are identical to those of $\mathrm{LF}_{2}$ except the loss of N-terminal Lys-Ala of $\mathrm{LF}_{2}$ in $\mathrm{LF}_{1}$. This manifests $\mathrm{LF}_{1}$ to be a truncated form of $\mathrm{LF}_{2}$. The N-terminal sequence of $\mathrm{LF}_{3}$ is completely identical to those of $\mathrm{LF}_{2}$, suggesting that they share with the same protein core. Taken together, the smaller molecular size of $\mathrm{LF}_{3}$ as compared with $\mathrm{LF}_{2}$ is attributed to their difference in the $\mathrm{N}$-glycoconjugates.

\subsection{Tissue distribution of $L F$}

Based on the molecular mass of immunoreactive $\mathrm{LF}_{2}$ band in Western analysis shown in Fig. 3, either a $M_{\mathrm{r}} 70000$ protein or a $M_{\mathrm{r}} 74000$ one, but not both, was immunoreacted with the purified $\mathrm{LF}_{2}$ antibody in the blot pattern of western analysis for $100 \mu \mathrm{g}$ of proteins in each tissue homogenate of mature mice (Fig. 5). In the non-sexual organs the $M_{\mathrm{r}} 74000 \mathrm{LF}$ was detected in spleen, lung and heart but no LF was detected in stomach and intestine. The latter was not attributed to the technical problem of Western blot procedures, because the transfer of LF from the polyacrylamide slab gel to PVDF membrane was almost complete and the detection of LF on the membrane could reach a low limit of $50 \mathrm{ng}$. Relatively, the $M_{\mathrm{r}} 74000 \mathrm{LF}$ seemed to exist in liver and kidney. In the reproductive tracts, the $M_{\mathrm{r}} 74000$ LF was detected in vagina and uterus, but the $M_{\mathrm{r}}$ $70000 \mathrm{LF}$ was found in the Vas Deferens and epididymis. We detected traces of LF in ovary and prostate and no LF in testis and seminal vesicle. Based on the immunostaining intensity, LF is abundant in epididymis and vagina as compared the amount of LF in other sexual organs. This is congruent with the previous result detected by enzyme-linked immunosorbent assay (ELISA) [20]. Because of the absence of LF mRNA in vas deferens, the appearance of LF in this organ is likely from epididymal secretion [20]. The vagina is among the female sexual organs and the epididymis is 


\section{(A)}

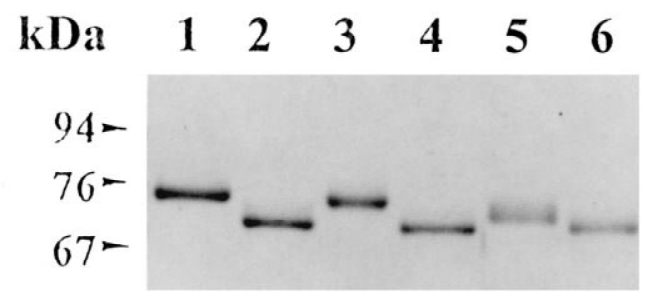

(B)

\begin{tabular}{|c|c|c|}
\hline Source & Signal peptide & Junction \\
\hline & -19 & +1 \\
\hline & : & : \\
\hline \multirow[t]{2}{*}{ Pig } & MKLFIPALLFLGTLGLCLA & APKKGVRWCVISTAEYSKCRQW \\
\hline & $1 ! 1111111111111111$ & \\
\hline \multirow[t]{2}{*}{ Bovine } & MKLFVPALLSLGALGLCLA & APRKNVRWCTISQPEWFKCRRW \\
\hline & 11111111111111111111 & \\
\hline \multirow[t]{2}{*}{ Got } & MKLFVPALLSLGALGLCLA & APRKNVRWCAISLPEWSKCYQW \\
\hline & 111111111111111 & \\
\hline \multirow[t]{2}{*}{ Human } & MKLVFLVLLFLGALGLCLA & GRRRRSVQWCAVSQPEATKCFQW \\
\hline & 11111.1111111 & \\
\hline \multirow[t]{2}{*}{ Mouse $(C D-1)$} & MRLIIPSLIFLËALGLCLA & KATTVRWCAVSNSEEEKCLRW \\
\hline & & 1111111111111111111 \\
\hline \multirow[t]{2}{*}{$L F_{1}$} & & TTVRWXAVSNSEEEKXI \\
\hline & & 11111111111111111111 \\
\hline \multirow[t]{2}{*}{$\mathrm{LF}_{2}$} & & KATTVRWXAVSNSEEEKXI \\
\hline & & 1111111111111111111 \\
\hline $\mathrm{LF}_{3}$ & & KATTVRWXAVSNSEEEKXI \\
\hline
\end{tabular}

Fig. 4. Characterization of LFs. (A) Determination of molecular size by SDS-PAGE. $\mathrm{LF}_{1}$ and $\mathrm{LF}_{2}$ of Fig. $1 \mathrm{~A}$ and $\mathrm{LF}_{3}$ were digested with $N$-glycosidase F. The protein sample $(1 \mu \mathrm{g})$ was subjected to SDS-PAGE on an $8.0 \%$ gel slab: lane 1 , $\mathrm{LF}_{1}$; lane 2 , the digested $\mathrm{LF}_{1}$; lane 3 , $\mathrm{LF}_{2}$; lane 4, the digested $\mathrm{LF}_{2}$; lane $5, \mathrm{LF}_{3}$; lane 6, the digested $\mathrm{LF}_{3}$. The gel was stained with $0.1 \%$ Coomassie Brilliant Blue. (B) Alignment of the signal peptide sequences of mammal LFs and the $\mathrm{N}$-terminal sequences of $\mathrm{LF}_{1}, \mathrm{LF}_{2}$ and $\mathrm{LF}_{3}$. Signal peptide sequences of several LFs and the junction with mature protein are aligned. Vertical lines denote the conserved residues. The glutamate residue in mouse LF is indicated by a dot. The $\mathrm{N}$-terminal sequences of $\mathrm{LF}_{1}, \mathrm{LF}_{2}$ and $\mathrm{LF}_{3}$ were obtained from automated Edman degradation. The cDNA-deduced amino acid sequences of LF in ULF of CD-1 mice are listed for comparison. " $\mathrm{X}$ " represents an unidentified amino acid, which is most likely to be Cys, in the amino acid sequence determination by automated Edman degradation.

among the male sexual organs to contain a higher LF concentration.

\section{Discussion}

Among the reproductive tracts of adult mice, LF is mainly distributed in epididymis, uterus and vagina. LF isolated from ULF of CD-1 mice was claimed to have a blocked $\mathrm{N}$-terminus [16], but the $\mathrm{N}$-terminal Lys of LF isolated from mouse milk is not blocked [27]. The N-termini of LFs purified from several species of mammal are not blocked also. This work reveals the microheterogeneity of LF in the reproductive tracts of ICR mice. Two forms, $\mathrm{LF}_{1}$ and $\mathrm{LF}_{2}$, are present in ULF and one form, $\mathrm{LF}_{3}$, exists in epididymis. Our results indicate that: (a) they are glycoproteins with the $\mathrm{N}$-linked glycoconjugate in 


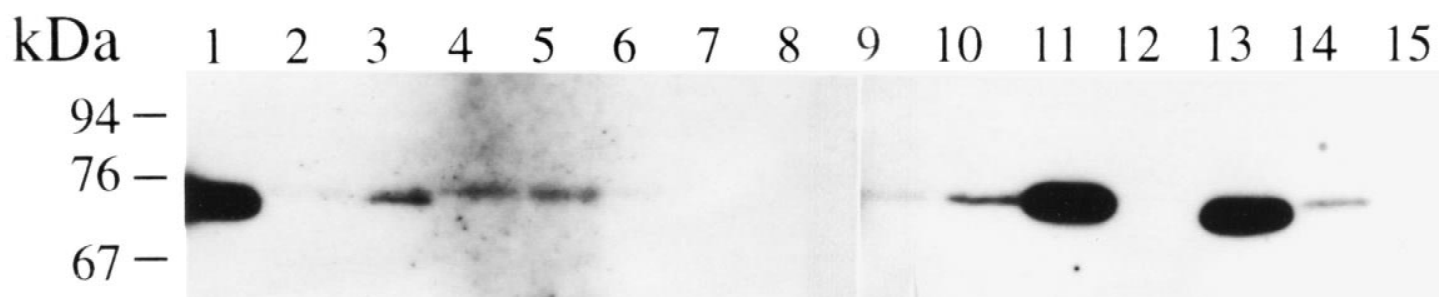

Fig. 5. Reexamination of the tissue distribution of LF in various mouse tissues. One hundred $\mu \mathrm{g}$ of protein from each tissue homogenate was resolved by SDS-PAGE on an $8.0 \%$ gel slab, transferred to a PVDF membrane and immunodetected by Western blot procedures with the purified $\mathrm{LF}_{2}$ antibody (see Section 2.5). Tissues examined are Vas Deferens (lane 1), kidney (lane 2), spleen (lane 3), lung (lane 4), heart (lane 5), liver (lane 6), stomach (lane 7), intestine (lane 8), ovary (lane 9), uterus (lane 10), vagina (lane 11), testis (lane 12), epididymis (lane 13), prostate (lane 14), and seminal vesicle (lane 15).

nature; (b) their N-terminal residues are not blocked and can be determined directly by Edman degradation; (c) they may share the same protein core except the deletion of the N-terminal Lys-Ala of $\mathrm{LF}_{2} / \mathrm{LF}_{3}$ in $\mathrm{LF}_{1}$; (d) $\mathrm{LF}_{1}$ and $\mathrm{LF}_{2}$ may have similar glycan content if not identical glycan chain composition, and $\mathrm{LF}_{3}$ contains less amount of carbohydrate than $\mathrm{LF}_{1} / \mathrm{LF}_{2}$. Apparently, the microheterogeneity of LF arises from the different post-translational cleavage of a precursor protein or the different extent of glycosylation on a putative protein.

The signal peptide of an eukaryotic protein usually contains a hydrophilic N-terminal domain with net positive charge, a hydrophobic core domain of at least seven residues and a polar C-terminal domain of 4-6 residues which comprise Pro or Gly that interrupts the ordered secondary structure in order to facilitate the post-translational cleavage. The typical tripartite domain occurs in the 19 amino acid residues of signal peptide in each mammalian LF listed in Fig. 4B. There appears a highly conserved 10 residues, namely ${ }^{-10}$ FLGALGLCLA $^{-1}$, in the Cterminal region in which $\mathrm{Gly}^{-8}$ is mutated to Glu in mouse LF. As mentioned in the previous works [28], the presence of a charged residue in the hydrophobic region of a signal peptide may affect the cleavage efficiency or/and the cleavage site by signal peptidase. This seems to happen in the generation of $\mathrm{LF}_{1}$ and $\mathrm{LF}_{2}$. The post-translational cleavage sites at $\mathrm{Ala}^{-1}$ and $\mathrm{Ala}^{+2}$ in the yield of $\mathrm{LF}_{1}$ and $\mathrm{LF}_{2}$ are not contradictory to $(-3,-1)$ rule, which states a small and neutral residue at positions -1 and -3 relative to the cleavage site of signal peptide [29]. In fact, the post-translational cleavage site other than the wild- type site has been found in the precursor of bovine growth hormone [30] and artificial mutant [31].

The association of LF with serum albumin is well known $[32,33]$. We made a great effort to prepare the $\mathrm{LF}_{2}$ antibody with no crossactivity to mouse serum albumin. The antibody immunoreacted only with the $M_{\mathrm{r}} 70000$ or $74000 \mathrm{LF}$, which is distinct from $M_{\mathrm{r}}$ 65000 serum albumin, in the Western analysis of tissue homogenates (Fig. 5). This excludes the existence of a LF with a molecular mass similar to serum albumin as suspected in the previous reports $[16,17]$.

\section{Acknowledgements}

This work was partially supported by a grant (NSC 88-2311-B-001-012) from National Science Council, Taiwan. We thank the technical assistance from Mr. Shui-Tsung Chen of our institute.

\section{References}

[1] P.L. Masson, J.F. Heremans, Comp. Biochem. Physiol. 39B (1971) 119.

[2] P.L. Masson, J.F. Heremans, C. Dive, Clin. Chim. Acta 14 (1966) 735.

[3] T. Rado, J. Bollekens, G. St. Laurent, L. Parker, E.J. Benz Jr., Blood 64 (1984) 1103.

[4] J.H. Brock, Arch. Dis. Child. 55 (1980) 417.

[5] R.R. Arnold, M.F. Cole, J.R. McGhee, Science 197 (1976) 263.

[6] W. Bellamy, M. Takase, K. Yamauchi, H. Wakabayashi, K. Kawase, M. Tomita, Biochim. Biophys. Acta 1121 (1992) 130. 
[7] L. Lu, G. Hangoc, A. Oliff, L.T. Chen, R.N. Shen, H.E. Broxmeyer, Cancer Res. 47 (1987) 4184.

[8] P. Gentile, H.E. Broxmeyer, Blood 61 (1983) 982.

[9] L. Sanchez, M. Calvo, J.H. Brock, Arch. Dis. Child. 67 (1992) 657.

[10] B. Lonnerdal, S. Iyer, Annu. Rev. Nutr. 15 (1995) 93.

[11] J. He, P. Furmanski, Nature 373 (1995) 721.

[12] M.S. Cohen, B.E. Britigan, M. French, K. Bean, Am. J. Obstet. Gynecol. 157 (1987) 1122.

[13] P.F. Tauber, L.J.D. Zaneveld, D. Propping, G.F.B. Schumacher, J. Reprod. Fertil. 43 (1975) 249.

[14] S.A. Goodman, L.G. Young, J. Reprod. Immunol. 3 (1981) 99.

[15] B.T. Pentecost, C.T. Teng, J. Biol. Chem. 262 (1987) 10134.

[16] C.T. Teng, B.T. Penticost, Y.H. Chen, R.R. Newbold, E.M. Eddy, J.A. McLachlan, Endocrinology (Baltimore) 124 (1989) 992.

[17] D.K. Walmer, M.A. Wrona, C.L. Hughes, K.G. Nelson, Endocrinology 131 (1992) 1458.

[18] R.R. Newblod, C.T. Teng, W.C. Beckman, W.N. Jefferson Jr., R.B. Hanson, J.V. Miller, J.A. McLachlan, Biol. Reprod. 47 (1992) 903.

[19] M.T. McMaster, C.T. Teng, S.K. Dey, G.K. Andrews, Mol. Endocrinol. 5 (1992) 101.
[20] L.C. Yu, Y.H. Chen, Biochem. J. 296 (1993) 107.

[21] Y.Z. Jin, S. Bannai, F. Dacheux, J. Dacheux, N. Okamura, Mol. Reprod. Dev. 47 (1997) 490.

[22] J.J. Rogerts, J.C. Boursnell, J. Reprod. Fertil. 42 (1975) 579.

[23] W.J. Hurley, R.C. Grieve, C.E. Magura, H.M. Hegarty, S. Zou, J. Dairy Sci. 76 (1993) 377.

[24] A.L. Tarentino, T.H. Plummer Jr., Methods Enzymol. 230 (1994) 44.

[25] U.K. Laemmli, Nature (Lond.) 227 (1970) 680.

[26] C. Schneider, R.A. Newman, D.R. Sutherland, U. Asser, M.F. Greaves, J. Biol. Chem. 257 (1982) 10766.

[27] J.M. Kinkade, W.W.K. Miller III, F.M. Segars, Biochim. Biophys. Acta 446 (1976) 407.

[28] M.P. Caulfield, L.T. Duong, R.K. Baker, M. Rosenblatt, M.O. Lively, J. Biol. Chem. 264 (1989) 15813.

[29] G. Von Heijne, Eur. J. Biochem. 133 (1983) 17.

[30] V.R. Lingappa, A. Thiery-Devillers, G. Blobel, Proc. Natl. Acad. Sci. USA 74 (1977) 2432.

[31] R.J. Folz, S.F. Nothwehr, J.I. Gordon, J. Biol. Chem. 263 (1988) 2070.

[32] A. Hekman, Biochim. Biophys. Acta 251 (1971) 380.

[33] F. Lampreave, A. Pineiro, J.H. Brock, L. Sanchez, M. Calvo, Intern. J. Biol. Macrom. 12 (1990) 2. 